Letrônica, Porto Alegre, v. 7, n. 2, p. 1010-1028, jul./dez., 2014

\title{
VIAGENS IMAGINÁRIAS EM PRIMEIRAS ESTÓRIAS DE GUIMARÃES ROSA
}

\author{
IMAGINARY JOURNEYS ON PRIMEIRAS ESTÓRIAS BY GUIMARÃES ROSA
}

\author{
Maria Carolina de Godoy*
}

\begin{abstract}
Resumo: A proposta deste trabalho é analisar o tema da viagem no livro Primeiras estórias (1972) de Guimarães Rosa, mais especificamente, nos contos "Pirlimpsiquice", "Partida do audaz navegante" e "Nenhum, nenhuma". As versões da peça encenada em "Pirlimpsiquice", bem como as modificações da personagem Brejeirinha no trânsito para a história do audaz navegante, fazem parte da viagem ao mundo da invenção e da liberdade de criação. Em "Nenhum, nenhuma", o enigma da viagem consiste em não se poder precisar se o espaço descrito corresponde a um local visitado pelo Menino ou a visões de um sonho do narrador adulto que tenta unir fios do passado e emoldurar a essência do tempo. 0 imaginário da criança é descortinado ao criar histórias e a viagem torna-se o adentramento nesse universo infantil. As reflexões estão apoiadas em estudos do narrador e mantêm diálogos com ensaios críticos sobre a obra de Guimarães Rosa.
\end{abstract}

Palavras-chave: Viagem; Universo infantil; Narrador.

\begin{abstract}
The aim of this paper is to analyze the theme of travel in the work Primeiras Estórias (1972) by Guimarães Rosa, more specifically, in the tales "Pirlimpsiquice", "Partida do audaz navegante" and "Nenhum, nenhuma." The versions of the piece in "Pirlimpsiquice" as well as the new modifications of the character Brejeirinha to the history of the daring navigator are part of the journey to the world of invention and creative freedom. In "Nenhum, nenhuma," the enigma of the journey is to be able to not precise if the described space corresponds to a location visited by the boy or the visions of a dream of the adult narrator who tries to unite the wires of the past and frame the essence of time. The imaginary of the child is revealed when stories are created and the journey becomes the indentation in the infant universe. The reflections are supported by studies of the narrator and maintain dialogues with the critical essays on the work of Guimarães Rosa.
\end{abstract}

Keywords: Journeys; Infant universe; Narrator.

Brejeirinha, ao lado dos garotos do teatro em "Pirlimpsiquice" e do Menino da nebulosa narrativa de "Nenhum, nenhuma", encontra-se em espaço aberto à recriação da realidade, no imaginário, em viagem enigmática compreendida no âmbito da criatividade. As personagens, nesses contos, não saem em viagem, deslocando-se de um ponto ao outro em seu percurso de aprendizagem; o significado de viajar consiste em evadir-se dos limites impostos pela realidade e navegar - para se usar uma

\footnotetext{
${ }^{*}$ Professora Adjunta da Universidade Estadual de Londrina e pesquisadora associada da Universidade Federal do Rio de Janeiro. Este trabalho consiste em reflexões desenvolvidas na tese de doutorado defendida na UNESP-Araraquara sob a orientação da Prof ${ }^{a}$ Livre-docente Maria Célia de Moraes Leonel.
} 
denominação significativa no campo semântico da viagem - nos atalhos da arte de narrar, de representar ou, ainda, no ato de rememorar. Nessas narrativas, um mundo imaginário se forma, desprende-se do real para se transformar em refúgio do aprendizado.

\section{Brejeirinha e a viagem do navegante audaz}

Ciganinha, Pele e Brejeirinha - elas brotavam num galho. Só o Zito, este, era de fora; só primo. Meia-manhã chuvosa entre verdes: o fúfio fino borrifo, e a gente fica quase presos, alojados, na cozinha ou na casa, no centro de muitas lamas. (ROSA, 1972, p.115).

Assim, de súbito, adentra-se o convívio entre as crianças em "Partida do audaz navegante"; a despeito da inserção repentina na narrativa é possível perceber a delicadeza com que o narrador situa personagens no espaço e esclarece o parentesco entre elas. 0 barulhinho do vento é captado sutilmente, sem rupturas com o quadro delineado na narrativa de uma manhã chuvosa, úmida, que isola narrador e narratário, personagens e acontecimentos. Tem-se a impressão de proximidade com o universo da criança neste conto em que todos parecem participar da convivência com o campo misterioso da fantasia infantil:

0 narrador rosiano é capaz de modular e modificar sua própria voz à medida que a enunciação se desenvolve. Enquanto narra, ele mesmo, narrador rosiano, ilumina-se de saber e por isso delineia-se a si próprio durante seu fazer discursivo. Os limites entre focalização homo ou heterodiegética mostram-se diluídos tanto quanto os limites entre focalização interna ou externa. (RUNHO, 1996, p. 95).

A questão que se instaura desde o início é: de onde fala o narrador? 0 uso, em tom coloquial e íntimo, da expressão "a gente", em toda a narrativa, quebra a ilusão habitual de um narrador distante dos fatos e fragiliza a objetividade, substituída, assim, pela subjetividade, característica fundamental do narrador rosiano. A predominância dos verbos no imperfeito do indicativo que se alternam com o presente dissolve limites entre tempo da narração e da história (diegese), outra particularidade rosiana. 0 uso desse tempo verbal, para Fiorin,

apresenta os fatos como simultâneos, como formando um quadro contínuo, ou melhor, como vinculados ao mesmo momento de referência pretérito. Por isso, 
é o tempo que melhor atende aos propósitos da descrição [...] que gera um efeito de sentido de estaticidade. (FIORIN, 1996, p. 158).

Nesse conto, em especial, essa peculiaridade narrativa propicia a completa inserção do leitor no imaginário infantil, estimulado pela troca de experiências entre as crianças que, juntas, desprendem-se do espaço fechado da casa, do contato direto com a mãe, caminham em direção ao quintal e depois ao rio, espaço aberto, estímulo maior para a imaginação; saem no ritmo de aventureiros, audazes navegantes:

Então, pediu-se licença de ir espiar o riachinho cheio. Mamãe deixava, elas não eram mais meninas de agarra-a-saia. De impulso, se alegraram. Só que alguém teria de junto ir, para não se esquecerem de não chegar perto das águas perigosas. 0 rio, ali, é assaz. Se o Zito não seria, próprio, essa pessoa de acompanhar, um meiozinho-homem, leal de responsabilidades? Cessou-se a cerração do ar. Mas tinham de vestir outras roupas quentes. - "Oh, as grogrolas!" Brejeirinha de alegria ante todas, feliz como se, se, se: menina só ave. - "Vão com Deus!" - Mamãe disse, profetisa, com aquela voz voável. Ela falava, e choviam era bátegas de bênçãos. A gentezinha separou-se. (ROSA, 1972, p.118)

São perceptíveis o aconchego, o carinho e a alegria que circundam as personagens em vista da referência à imagem da mãe e da suavidade das descrições, tão delicadas e sutis quanto os contornos pueris. 0 discurso narrativo apresenta-se salpicado de adjetivos ao lado de substantivos no diminutivo com valor semântico afetivo. Os sufixos formadores do diminutivo presentes desde os nomes das personagens centrais, Ciganinha e Brejeirinha, causam a sensação de delicadeza e cuidado dispensados pelo narrador. A voz do narrador que parece brotar em meio às aventuras das personagens, na chuva e no barro, assume a infância em plenitude.

Luzes e limbos, eis a dialética da antecedência do ser de infância. Um sonhador de palavras não pode deixar de mostrar-se sensível à doçura da palavra que põe luzes e limbos sob o império de duas labiadas. Com a luz, há água na claridade e os Limbos são aquáticos. (BACHELARD, 2001, p. 106).

A sensibilidade do narrador transborda em diminutivos que não se restringem à função descritiva quando expõem um "meio estilístico que elide a objetividade sóbria e a severidade da linguagem, tornando-a mais flexível e amável" (CUNHA, 1977, p.209). "Cruzadinha", "perfilzinho", "narizinho que-carícia", "chuvinha", "briguinha", "infimículas", "boazinha", "babinhas", "analfabetinha", "beatinha", "riachinho", "meiozinho-homem", "gentezinha", "ladeirinha" são alguns exemplos, dentre vários, que povoam o discurso narrativo do conto e captam a criatividade infantil em movimento, 
passando para primeiro plano o fluxo da infância que se encontra menos nas atividades intensas das personagens, do que na arte de contar da protagonista. É a brincadeira de contar e ouvir histórias que move as personagens, estimuladas pela animação peculiar ao grupo de crianças que se isolam em seu mundo de faz de conta:

\begin{abstract}
Por vezes as crianças entre si quase que criam este "outro mundo" ao qual muitos autores aspiram. Em geral esta vida separada dura pouco. Ela se desenvolve durante períodos privilegiados: primeiros anos, férias, situações excepcionais. Os valores da sociedade adulta e suas práticas são aí rejeitados ou plagiados, ou interpretados sem constrangimentos. Algumas vezes, no entanto, eles perturbam as relações. Este mundo está fadado à destruição direta pelos adultos, ou indireta, pela idade que transforma as crianças ou, ainda, pelas necessidades da integração à vida social. (CHOMBART-DELAUWE, 1991, p. 155).
\end{abstract}

Em "Partida do audaz navegante" a voz do narrador familiariza-se com o universo doméstico de tal forma que sugere aproximação com os acontecimentos, em posição de testemunha:

\begin{abstract}
Mamãe, ainda de roupão, mandava Maria Eva estrelar ovos com torresmos e descascar os mamões maduros. Mamãe, a mais bela, a melhor. Seus pés podiam calçar as chinelas de Pele. Seus cabelos davam o louro silencioso. Suas meninas-dos-olhos brincavam com bonecas. [...] Meia-manhã chuvosa entre verdes: o fúfio fino borrifo, e a gente fica quase presos, alojados, na cozinha ou na casa, no centro de muitas lamas. [...] Mamãe cuida com orgulhos e olhares as três meninas e o menino. Da Brejeirinha, menor, muito mais. Porque Brejeirinha, às vezes, formava muitas artes. (ROSA, 1972, p. 115).
\end{abstract}

Os recursos do uso do presente e da expressão "a gente" substituem a necessidade de se ter um narrador em primeira pessoa (protagonista ou testemunha) para se acompanhar de perto o desenvolvimento da história primeira: um dia chuvoso na vida das crianças. Ao mesmo tempo, a opção pela terceira pessoa, às vezes mais distante, proporciona a visão de um quadro, como se o afastamento do narrador focalizador oferecesse a distância exata para um instantâneo das expressões da personagem, cujo convite à participação de outro olhar (do leitor) permanece na expressão "a gente":

Brejeirinha se instituíra, um azougue de quieta, sentada no caixote de batatas. Toda cruzadinha, traçadas as pernocas, ocupava-se com a caixa de fósforos. A gente via Brejeirinha: primeiro, os cabelos, compridos, lisos, louro-cobre. (ROSA, 1972, p. 115)

Ou se convida para olhar junto com a personagem: 
Aos tantos, não parava, andorinhava, espiava agora - o xixixi e o empapar-se da paisagem - as pestanas til-til. Porém, disse-se-dizia ela, pouco se vê, pelos entrefios: - "Tanto chove, que me gela!". (ROSA, 1972, p.115, grifos do autor).

Nessa manhã "que brumava e chuviscava" e "parecia não acontecer coisa nenhuma" (ROSA, 1972, p.115) o clima propício à criação de histórias preenche o cenário para Brejeirinha, alegre e criativa desde o nome, assumir o papel de contadora para os irmãos. Ao se deslocar a focalização para Brejeirinha, que se destaca por inquietantes indagações "'Eu sei porque é que o ovo se parece com um espeto! [...] Eu queria saber o amor..." (ROSA, 1972, p.116, grifos do autor), pode-se acompanhar o aprendizado desta personagem, em cujas versões de uma história inscrevem-se as tentativas de querer compreender o sentimento amoroso, inspirada pela relação entre a irmã Ciganinha e o primo Zito. A brincadeira com palavras pouco conhecidas dirigida ao primo, constrangido por uma briga com Ciganinha, provoca sua expressão de descontentamento:

\begin{abstract}
"Zito, tubarão é desvairado, ou é explícito ou demagogo?" Porque gostava, poetista, de importar desses sérios nomes, que lampejam longo clarão no escuro de nossa ignorância. Zito não respondia, desesperado de repente, controversioso-culposo, sonhava ir-se embora, teatral, debaixo de chuva que chuva, ele estalava numa raiva. Mas Brejeirinha tinha o dom de apreender as tenuidades: delas apropriava-se e refletia-se em si - a coisa das coisas e a pessoa das pessoas. (ROSA, 1972, p. 117).
\end{abstract}

A abrupta mudança de comportamento de Zito, instigada e acompanhada pela protagonista capaz de individualizá-lo, é o mote necessário à invenção de um marujo, projeção inicial do rapazinho. É em Brejeirinha que se concentra a narrativa, como observa Rosiane Cristina Runho:

A focalização é interna mais fortemente em relação à Brejeirinha e é através dela - de seus pensamentos e percepções - que, muitas vezes, o narrador aproxima-se das outras crianças. Desse modo, valendo-se também das impressões historiadas de Brejeirinha - relatora no nível intradiegético, capaz de apreender os sentimentos do primo e da irmã apaixonados - o narrador compõe a linha narrativa ao nível extradiegético: a história de aprender amor entre Zito e Ciganinha. (RUNHO, 1996, p. 142).

É interessante observar que o aprendizado amoroso ou a viagem ao encontro do amor é retratado em outro conto de Primeiras Estórias intitulado "Sequência" cuja narrativa conta a história de uma vaca que desencadeia a viagem e, autômato, um 
vaqueiro sai à sua procura até encontrar uma moça. Benedito Nunes comenta essa viagem para o amor:

\begin{abstract}
Paralelamente, invoquemos o vaqueiro da estória "Sequência", que saindo à procura de uma vaca extraviada, descobre, de repente, ao entrar no pátio da fazenda, para onde se encaminhara a fugitiva, qual era o verdadeiro objeto da sua busca: o amor da moça que se debruçava no alpendre da casa. 0 animal "rês fuja" -, que abandona os pastos, atravessa um rio, e percorre os atalhos, tem a sua razão oculta. Apenas um elo mediador, a vaca é o signo de objeto amado. (NUNES, 1969, p.152),
\end{abstract}

Sobre o motivo da viagem em Guimarães Rosa, o autor acrescenta que:

Através do motivo da viagem, que está presente em quase toda a sua obra, de Sagarana a Primeiras Estórias, Guimarães Rosa liga-se às grandes expressões do "romance de espaço" - ao D.Quixote de Cervantes e ao Ulisses de Joyce, para só falarmos dos extremos dessa espécie, em que a narração dos acontecimentos e peripécias se apresenta como a primeira camada da criação romanesca, intermediária da descoberta do mundo natural e humano. (NUNES, 1969, p. 173).

Para prosseguir na descoberta do mundo natural e humano, no sentido sugerido pelo crítico, a personagem de "Partida do audaz navegante" explora a capacidade inventiva e, na medida em que sua criação se projeta no mundo imaginário, as intersecções com a realidade - o amor entre o primo e a irmã - ficam frágeis. Há exploração não apenas do tema da viagem, mas da figurativização desse tema na imagem de um navegante. A viagem associada ao barco é considerada por Chombart-deLauwe (1991) tema por excelência do mundo da criança:

No mundo imaginário existe, frequentemente, confusão entre o agente e o paciente: ou a criança é testemunha de uma viagem, de um deslocamento de personagem ou, então, na maioria das vezes, ela própria viaja. Ela toma emprestado um barco, um bote, cavalga uma nuvem. Os autores gostam de associar a criança que sonha ao esquife, símbolo de proteção, de berço que embala, assim como à água, um símbolo materno frequente. (CHOMBART-DELAUWE, 1991, p. 112).

Na primeira versão, o Aldaz Navegante, reflexo do primo, distancia-se de todos para descobrir novos lugares, sem olhar para trás: "'Ele deve de ter, então, a alguma raiva de nós, dentro dele, sem saber..."' (ROSA, 1972, p.117); projeta-se, assim, a tristeza e a solidão da personagem Zito em virtude da briga com Ciganinha. Sob protestos, Brejeirinha se mantém reflexiva em sua intensa atividade de brincar com palavras "'Antes falar bobagens, que calar besteiras...'" (ROSA, 1972, p.117). Conforme os ouvintes e a contadora se afastam da casa em direção ao riacho, quando a chuva cessa, o 
passeio aproxima os enamorados. Novo olhar sobre o amor, merece nova versão da narrativa do marujo, agora duvidoso quanto ao dever partir de uma moça:

o Aldaz Navegante não gostava de mar! Ele tinha assim mesmo de partir? Ele amava uma moça, magra. Mas o mar veio, em vento, e levou o navio dele, com ele dentro, escrutínio. 0 Aldaz navegante não podia nada, só o mar, danado de ao redor, preliminar. o Aldaz Navegante se lembrava muito da moça. 0 amor é original. (ROSA, 1972, p. 120, grifos do autor)

Em meio à tempestade, o navegante perde o navio, levado pela chuva. A representação do desconforto e da inquietação causados pelo amor, parece se configurar nessa tormenta e a personagem Aldaz não só se desvencilha do reflexo do primo, mas também passa a ser identificada com o sentimento amoroso:

"A moça estava paralela, lá, longe, sozinha, ficada, inclusive, eles dois estavam nas duas pontinhas da saudade... 0 amor, isto é... o Aldaz Navegante, o perigo era total, titular... não tinha salvação... 0 Aldaz... 0 Aldaz..." (ROSA, 1972, p. 120, grifos do autor)

Em abstração absoluta, a aprendizagem do amor pode ser reconhecida na história e através da história inventada, em que se evidenciam a liberdade do ato de criar em si e a exploração de algumas das infinitas possibilidades de mudar os rumos da história ou de criar símbolos, exercício do artista. A viagem do Aldaz Navegante, após ser cumprida a trajetória de aprender a navegar e a amar, pode desprender-se do imaginário, do ato de narrar, do signo e transmutar-se em objeto concreto: o esterco de gado. Novamente, entra em cena a capacidade criativa, ao se imaginar um navegante na massa disforme, atingindo-se o ápice da liberdade de criação e inventividade, na concretização da metamorfose estético-literária:

Brejeirinha saltava e agia, rápida no valer-se das ocasiões. Apanhara aquelas florinhas amarelas [...] e veio espetá-las no concrôo do objeto. [...] - 'Pronto. É o Aldaz Navegante...'. (ROSA, 1972, p. 121, grifos do autor).

As duas últimas versões da narrativa acompanham, de um lado, a definitiva aproximação dos namorados e, de outro, a rapidez com que a enxurrada leva a matériamarinheiro na viagem que se afasta do mote original e, inversamente, torna-se exemplar para a experiência do amor:

Segredando-se, Ciganinha e Zito se consideram, nas pontinhas da realidade. "Hoje está tão bonito, não é? Tudo, todos, tão bem, a gente alegre... Eu gosto deste tempo..." E: "Eu também, Zito. Você vai voltar sempre aqui, muitas vezes? E: "Se Deus quiser, eu venho..." E: "Zito, você era capaz de 
fazer como o Audaz Navegante? Ir descobrir os outros lugares? E: "Ele foi, porque os outros lugares ainda são mais bonitos, quem sabe?..." (ROSA, 1972, p. 121, grifos do autor)

A brincadeira atinge o ápice, quando a história do Aldaz Navegante deixa de ser reflexo do amor entre Zito e Ciganinha e, autônoma, desprende-se do campo da imaginação para se concretizar em "coisa vacum" (o esterco de gado) no espaço da troca de experiências entre as personagens que "nas pontinhas da realidade [...] se disseram, assim eles dois, coisas grandes em palavras pequenas, ti a mim, me a ti, e tanto. Contudo, e felizes, alguma outra coisa se agitava neles, confusa-assim rosa-amor-espinhossaudade." (ROSA, 1976, p. 121-122)

A capacidade inventiva das crianças transgride os limites entre contar e vivenciar o que se conta, transfigurando o objeto ficcional, matéria narrada, em objeto-brinquedo, matéria palpável: "'Pronto. É o Aldaz Navegante..."' e Brejeirinha crivava-o de mais coisas-folhas de bambu, raminhos, gravetos. Já aquela matéria, o 'bovino', se transformava." (ROSA, 1976, p.121). Aos olhos das crianças, tudo se transforma em brinquedo:

ninguém é mais casto em relação aos materiais do que crianças: um simples pedacinho de madeira, uma pinha ou uma pedrinha reúnem na solidez, no monolitismo de sua matéria, uma exuberância das mais diferentes figuras. E ao imaginar para crianças bonecas de bétula ou de palha, um berço de vidro ou navios de estanho, os adultos estão na verdade interpretando a seu modo a sensibilidade infantil. Madeira, ossos, tecidos, argila, representam nesse microcosmo os materiais mais importantes, e todos eles já eram utilizados em tempos patriarcais, quando o brinquedo era ainda a peça do processo de produção que ligava pais e filhos. (BENJAMIN, 2002, p.92)

\section{Viagem e espetáculo em "Pirlimpsiquice"}

Em outro ambiente, fora do grupo familiar, a troca de experiências entre as personagens é motivada pelos jogos de representação. Os limites da peça do Dr. Perdigão em "Pirlimpsiquice", aparentemente estreitos e pré-determinados, ampliam-se quando a questão principal entre os alunos escolhidos para representá-la é preservar o segredo. Diante da necessidade de manter misteriosa a encenação, a narrativa ressalta o esforço despendido pelos garotos com a intenção de ocultá-la. 0 acordo em manter o sigilo os une, além da necessidade de ensaios ou de boas relações a fim de que a representação tenha êxito: 
'Ninguém conta nada aos outros, do drama!' Concordados, combinou-se, juramos. Careciam-se uns momentos, para a grandiosa alegria se ajustar nos cantos das nossas cabeças. A não ser o Zé Boné, decerto. (ROSA, 1972, p.40 grifos do autor).

Companheiro menos prestigiado entre os atores escolhidos, no recreio, Zé Boné vive em suas representações solitárias e, por isso, não desperta confiança. De um lado, o padre Diretor e o Dr. Perdigão, símbolos da ordem, propõem a peça previamente escolhida, "Os filhos do Doutor Famoso"; de outro, colegas não selecionados ameaçam boicotar a apresentação, incitando a desordem; no limiar, a personagem Zé Boné, apresentando visíveis dificuldades para o papel, não assume completamente seu lugar na peça (espaço de dentro) ou entre os alunos excluídos (espaço de fora).

Os doze alunos escolhidos para representar o drama "Os Filhos do Doutor Famoso" dividem-se em aplicados e maus alunos:

Percibimos que en la historia se oponen los partidos en lucha, que son principalmente el de los alumnos aplicados y el de los malos alumnos, esto es, el de los escogidos para la representación y el de los que se quedan afuera y por eso inventan otra historia para el teatro. Zé Boné está en una situación especial: escogido para la representación, por ser buen alumno, es objetado por los otros escogidos, que lo ven como incapaz de representar voces e de hacer teatro seriamente, haciendo una representación seria y organizada. Zé Boné queda por eso aislado, como una instancia paradojal, que oscila y circula entre varios grupos. (DUARTE, 2004, p. 45).

Em "Pirlimpsiquice", pela primeira vez, aparece o ambiente escolar entre as imagens da infância, remetendo ao aprendizado formal. Nesse conto, as personagens se preparam para a apresentação de um drama em cinco atos proposto pelo professor Dr. Perdigão. Originárias das lembranças de um dos participantes da peça, já adulto, a narrativa compõe-se do acontecimento anunciado. 0 espanto é visível desde o primeiro parágrafo do conto "Aquilo na noite de nosso teatrinho foi de Oh." (ROSA, 1972, p.39), aparecendo duplamente marcado pela interjeição "oh" pelo uso de um pronome demonstrativo "aquilo" indicativo do que não pode ser nomeado. À dificuldade em se recompor com precisão as cenas do ocorrido no dia da apresentação da peça, apesar de impressionante - "Ainda hoje adiante, anos, a gente se lembra: mas, mais do repente que da desordem, e menos da desordem do que do rumor" (p.39) - mesclam-se indagações sobre o destino dos colegas: "'E o em-diabo pretinho Alfeu, corcunda?'" (ROSA, 1972, p. 39). 
A tentativa de compreender o incrível daquela noite parece motivar o narrador à rememoração dos fatos, relatando a relevância de acontecimentos anteriores à grande estreia. Na rememoração, a representação teatral, ansiosamente aguardada pelos alunos, sobreleva-se ao ensino ou à significação do espaço escolar, pois "a sala de aula serve apenas de pano de fundo para as atividades da personagem; episódios mais ou menos importantes podem se desenrolar ali sem que, no entanto, o ensino ou a vida escolar sejam descritos ou julgados." (CHOMBART-DE-LAUWE, 1991, p. 343).

Há a transgressão, nesse conto, desse tipo de aprendizado formal já que a peça a ser representada é subvertida ao se criarem outras versões, dando espaço a pseudohistórias: "Precisávamos de imaginar, depressa, alguma outra estória, mais inventada, que íamos falsamente contar, embaindo os demais no engano. E, de Zé Boné, ficasse sempre perto um, tomando conta." (ROSA, 1972, p.40-41). À inventada para despistar os demais alunos (Tãozão e Mão-na-Lata) segue-se a história criada pelo colega Gamboa, que havia ficado de fora da peça: "De fato, circulava outra versão, completa, e por sinal bem aprontada, mas de todo mentirosa. Quem a espalhara? O Gamboa, engraçado, de muita inventiva e lábia, que afirmava, pés juntos, estar dono da verdade." (ROSA, 1972, p. 42).

Dr. Perdigão deixa transparecer a preocupação com a formação dos alunos; há, todavia, a força da criação emergente do mundo infantil que abre espaço para a explosão da criatividade, para o estranhamento da realidade e do outro:

As crianças entre si constroem uma sociedade à parte, em seu nível e que,
quando é livremente edificada, lhes permite uma vida mais autêntica. A
relação se estabelece entre semelhantes, entre "pares". Olhando uma criança, a
pequena personagem observa fenômenos em nível, que lhe concernem e que
ao mesmo tempo lhe ensinam a estranheza do "outro". (CHOMBART-DE-
LAUWE, 1991, p. 155).

Movidos pela situação periclitante, as personagens descobrem o potencial de invenção simbolizado desde o início pela personagem Zé Boné e, juntas, ousam aventurar-se em nova criação, que atrai expectadores: "Até o pretinho Alfeu, filho da cozinheira, e aleijado, voltava se arrastando com rapidez para a escutar, enquanto o Surubim não o via e mandava embora." (ROSA, 1972, p. 41). Nesse sentido, aproximamse da notável diversão de Brejeirinha em criar e recriar suas histórias.

A preocupação com as aulas ou outras atividades, às vezes, interrompe o movimento de ensaios: 
o Surubim dizia que o nosso teatro roubava ao ensino, e que não era verdade que, nas provas, iríamos ganhar boas notas de qualquer maneira. Possível? Mão-na-Lata estava combinando outro time, porque a gente mal treinava; misérias! (ROSA, 1972, p. 43).

Presos ao encantamento do faz-de-conta, da dinâmica ação de mostrar/ocultar a "verdadeira estória", as personagens parecem, sem se dar conta, recolhidas em mistérios, entrelaçadas nas linhas sutis da ficção, suspensas pelas cadeias da imaginação:

A encenação é a grande pausa criativa no trabalho educacional. Ela representa no reino das crianças aquilo que o carnaval representa nos antigos cultos. 0 mais alto converte-se no mais baixo de todos, e assim como em Roma, nos dias saturnais, o senhor servia ao escravo, assim também as crianças sobem ao palco durante a encenação e ensinam e educam aos atentos educadores. Novas forças, novas inervações vêm à luz, das quais frequentemente o diretor jamais teve qualquer vislumbre durante o trabalho. Ele vem a conhecê-las somente nessa selvagem libertação da fantasia infantil. Crianças que fizeram teatro dessa maneira libertam-se em tais encenações. A sua infância realizou-se no jogo. (BENJAMIN, 2002, p. 118-119).

A libertação a que se refere Walter Benjamin acontece, definitivamente, em "Pirlimpsiquice" no palco, lugar privilegiado capaz de abarcar não apenas uma, mas todas as histórias inventadas, próximas ou não da verdadeira ou primeira. É o lugar onde a vibração da magia ante o poder de ser vários ao mesmo tempo deixa em desalinho marcas da verdade ou da mentira. A concretização do "milmaravilhoso" advém da confusa apresentação da peça. Quando a esperada exposição desorganiza-se e recebe vaias, destaca-se Zé Boné, que provoca a reviravolta salvadora. Instaurada em outra ordem porque, segundo o narrador, ele "desempenhava um importante papel, o qual a gente não sabia qual" (ROSA, 1972, p. 46) e lança todos no encantamento que lhe é peculiar: "Contracenamos. Começávamos, todos, de uma vez, a representar a nossa inventada estória. Zé Boné também." (ROSA, 1972, p. 46). Todavia, a grande preparação para a liberdade do ato de representar, ad infinitum, fez-se ao longo de toda a narrativa, palco da representação literária:

Mas - de repente - eu temi? A meio, a medo, acordava, e daquele estro estrambótico. 0 que: aquilo nunca parava, não tinha começo nem fim? Não havia tempo decorrido. E como ajuizado terminar, então? Precisava. E fiz uma força, comigo, para me soltar do encantamento. (ROSA, 1972, p. 47). 
Ao desprender-se do encantamento, segue-se a certeza de que a verdade ou a mentira das histórias - da peça primeira ou das que dela brotaram - não se sobrepõe ao incrível daquela noite, ou à perturbação que motiva o narrador-protagonista a recompor o fato:

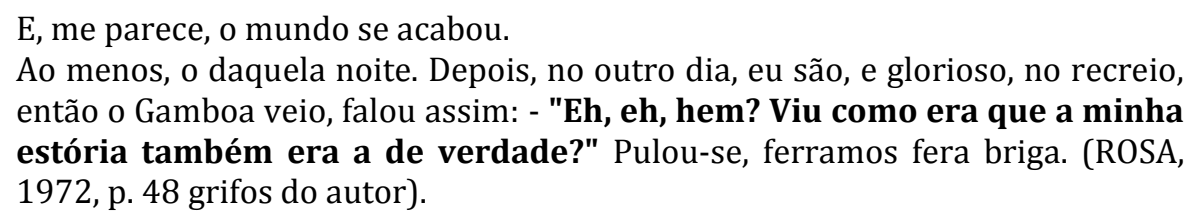
então o Gamboa veio, falou assim: - "Eh, eh, hem? Viu como era que a minha estória também era a de verdade?" Pulou-se, ferramos fera briga. (ROSA, 1972, p. 48 grifos do autor).

Ao visitar as fronteiras da verdade e da mentira em textos de Guimarães Rosa, Maria Célia Leonel (2005, p.107) observa que a "verdade (e a mentira) pode ser consequência da diversidade de opiniões ou mera questão de ponto de vista, do mesmo modo que a mentira - ou a verdade - pode ser apenas aparência". Acrescenta, sobre Grande sertão: veredas, que

\begin{abstract}
a ambivalência, a reversibilidade, a mescla entre o ser e o não ser, a impossibilidade de fixar a verdade e a mentira, o erro e o acerto que acompanham o discurso têm levado uma parte da crítica sobre o escritor a concluir que a obra enfeixa a ideia de que o que enforma o homem é a perplexidade. (LEONEL, 2005, p. 127).
\end{abstract}

Nas brincadeiras de inventar de Brejeirinha ou de representar dos garotos de "Pirlimpsiquice" sobressai o maravilhoso da ficção, espelhada na imaginação infantil. Imbuídas pela magia do "transviver", as personagens-atores confundem-se com suas histórias, absortas num mundo ficcional e isoladas (ou protegidas?) do rigor da imposição adulta e escolar representada pelo Dr. Perdigão em constante exaltação à importância da arte: "Representar é aprender a viver além dos levianos sentimentos, na verdadeira dignidade. [...] Longa é a arte e breve a vida..." (ROSA, 1972, p. 41-42).

\title{
3 Nebulosa viagem em "Nenhum, nenhuma”
}

É em clima de encantamento que um viajante aprendiz atravessa fronteiras, na narrativa de "Nenhum, nenhuma", entre sonho e realidade. Enquanto em "Pirlimpsiquice" a representação da realidade se distancia do individual e mistura-se na projeção exterior de uma história, a viagem do Menino aproxima-se da tentativa de 
reconstruir imagens individuais provenientes da memória de um "eu" que faz e se desfaz no entrecruzamento de presente, passado e futuro, dissipados na tênue (e imaginária) linha temporal. Misturam-se imagens de um Menino, de uma Moça e um Moço, um Velho e uma Velha, em projeção simultânea do tempo que parece ser o grande personagem do conto e a viagem metáfora de sua passagem.

A narrativa "Nenhum, nenhuma" significa certa ruptura no conjunto de narrativas selecionadas para este trabalho, visto que os eventos relatados e as impressões sobre eles estão de tal forma entrelaçados que, ao se tentar encontrar o fio condutor, corre-se o risco de se perder a teia enigmática de que é feito o conto. Admite-se a dificuldade em se isolar a personagem e acompanhar seu percurso ao lado de outras em vista da intensa simbologia sugerida pelo discurso. A dinâmica das ações das personagens parece se tornar rarefeita, quase imperceptível, seguindo o fluxo ininterrupto da rememoração representada no discurso. Menino, Moço, Moça, velha, homem sem aspecto são formas imprecisas que escapam à reconstituição da diegese, como ocorre em narrativas modernas em que

Muitas personagens, ou muitos fragmentos de acontecimentos são articulados por vezes frouxamente de tal forma que o leitor não consegue segurar constantemente qualquer fio condutor determinado. Há romances que procuram reconstruir um meio a partir de uma série de farrapos de acontecimentos, com personagens constantemente mutantes, por vezes reaparecidas. (AUERBACH, 1994, p. 491).

A rememoração de fatos, nesse conto, recupera o contínuo de uma realidade imensurável misturando tempo da narração e da história de um Menino, visitante:

Dentro da casa-de-fazenda, achada, ao acaso de outras várias e recomeçadas
distâncias, passaram-se e passam-se, na retentiva da gente, irreversos grandes
fatos-reflexos, relâmpagos, lampejos-pesados em obscuridade. A mansão,
estranha, fugindo, atrás de serras e serras, sempre, e à beira da mata de algum
rio, que proíbe o imaginar. Ou talvez não tenha sido numa fazenda, nem no
indescoberto rumo, nem tão longe? Não é possível saber-se, nunca mais.
(ROSA, 1972, p. 50).

Após o encontro com o homem, depara-se com a Moça "linda e recôndita." (ROSA, 1972, p.50) e com o Moço, entre olhares amorosos "um para o outro como os passarinhos ouvidos de repente a cantar" (ROSA, 1972, p.50). Conhece o amor dos jovens e, em seguida, depara-se com a velhice num quarto escondida. A Moça cuida do 
pai, o Homem velho da varanda, que está doente e de uma velha, Nenha, que não se sabe ao certo ser "tresbisavó de quem, nem de que idade, incomputada, incalculável" (ROSA, 1972, p.52). No jardim, o Menino se vê cercado por todos - Moço, Moça, Homem velho, Nenha - e assiste ao círculo do tempo (vida e morte) ao lado da permanência do amor que chega a lhe despertar ciúme. À experiência do amor segue-se a da dor de uma separação e, nesse mesmo jardim, presencia a separação do casal, em lágrimas; presencia eros cedendo lugar ao ágape:

A Moça, lágrimas em olhos, mas mediante o sorriso, linda já de outra espécie. Ela não concordou. Ela só olhava com enorme amor para o Moço. Então, ele deu-lhe as costas. E a Moça se ajoelhou, curvada para o berço da Nenha, velhinha, e chorava, abraçando-a - ela se abraçava com o incomutável, o imutável. (ROSA, 1972, p. 56).

O Menino sai pelo mesmo quarto, acompanhado do Moço que o leva de volta para casa e deixa um bilhete para a Moça sobre uma escrivaninha - apresentada também no início da narrativa. Sobre as cenas de entrada e saída, comenta Leyla Perrone-Moisés:

Tudo emana da escrivaninha vermelha, e para ela converge: ela guarda o imaginário romanesco da revista colorida; ela recebe a letra do bilhete cujo significado, ignorado, finalmente é o do próprio gesto de escrevê-lo e confiá-lo a um canal de comunicação inusitado e incerto. Depositária da memória, a escrivaninha concentra o real (da experiência tátil, olfativa e visual), o imaginário (da revista ilustrada) e o simbólico virtual (do bilhete). (PERRONEMOISÉS, 1990, p. 124).

O primeiro parágrafo do conto, constituído de períodos simples, denuncia imprecisão, exposta em substantivos abstratos e adjetivos cujas significações remetem a clarões de lembranças em meio à viagem pela escuridão do passado - "fatos-reflexos, relâmpagos, lampejos-pesados em obscuridade" (ROSA, 1972, p.50) . A indefinição do local dos acontecimentos, que parece ser numa mansão (fugindo da memória, talvez) próxima a algum rio, é reiterada pela oração alternativa "ou talvez não tenha sido" (ROSA, 1972, p.50) e pela interrogação. Nessa vaga abertura, abruptamente, a oração adversativa que introduz o segundo parágrafo - "Mas um menino penetrara no quarto, no extremo da varanda, onde se achava um homem sem aparência" (ROSA, 1972, p. 50) - insere a personagem infantil cuja trajetória de descobertas se acompanha na diegese.

A introspecção psicológica em "Nenhum, nenhuma", exemplar em Primeiras estórias, projeta a marca prosaica na inspeção das lembranças ou, nas palavras de 
Auerbach (1994, p.488-489), camadas que se libertam da sequência temporal exterior. Ana Paula Sá e Souza Pacheco (2002), ao analisar "Nenhum, nenhuma", considera que

\begin{abstract}
a maior beleza do conto esteja no modo como une a dificuldade de representar o passado à dificuldade de reaver uma identidade, a crise da representação à crise de identidade, mostrando como a arte só existe em relação com a vida. A forma difícil de "Nenhum, nenhuma" fala disso e de um esforço de reaver a integridade perdida, que corresponde, noutro plano, ao esforço do escritor, quando a arte se mostra como recusa da reificação. (SOUZA PACHECO, 2002, p. 57).
\end{abstract}

A dificuldade de representação do passado pode ser observada, na diegese, ao se tentar recompor o caminho percorrido pelo Menino, continuamente entrecortado de dúvidas e hesitações: "agora é que assoma, muito lento, o difícil clarão reminiscente, ao termo talvez de longuíssima viagem, vindo ferir-lhe a consciência." (ROSA, 1972, p.51). É desconhecida a motivação da viagem, sem que se possa explicitar o início desse percurso: "Àquela casa, como e por que viera ter o Menino? Talvez, em desviada viagem, sem pessoas da família. Sua estada esperara-se para mais curta, do que foi?" (ROSA, 1972, p.51). A ruptura, em momentos desse traçado, evidencia a importância da experiência e não do impulso inicial ou motivador, esclarecido apenas no final da narrativa. 0 Menino conhece, na viagem pela casa, representações da vivência com o homem sem aparência (o não reconhecimento de si mesmo)

sem aspecto tenta agora parecer-se com outro - um desses velhos tios ou conhecidos nossos, deles o mais silencioso. Mas, segundo se apurou, não era. Alguém mais, e os dois, o ignorado e o sabido, se perturbam. (ROSA, 1972, p. $50)$.

Na imagem da velha velhíssima, vê confundido o fim e o começo da vida:

Diziam ao Menino, demonstravam-lhe: que a Velhinha não era sombração, mas sim pessoa. Sem que lhe soubessem o verdadeiro nome, chamavam-na a "Nenha". Ela ficava tão quieta, no meio da alta cama de torneados, o catre com cabeceira dourada, que ali quase se sumia, nos panos, algo inviolável em sua exiguidade, e respirava. (ROSA, 1972, p. 53).

Reconhece o transbordante amor e a beleza na Moça e entende a abnegação e o sacrifício por amor com o Moço:

A Moça, de formosura tão extremada, vestida de preto, e ela era alta, alva, alva; parecia estar de madrinha num casamento, ou num teatro? Ela carregou o Menino, cheirava a vem de verde e a rosa, mais meigo que as rosas cheiram, mais grave. (ROSA, 1972, p. 53). 
Soturno, nervoso, o Moço não podia entender, considerar no impeditivo. Porque a Moça explicava: que não a morte do pai, nem da velhinha Nenha, de quem era a tratadeira. Falou:- "Mas a nossa morte..."[...] (ROSA, 1972, p. 55, grifos do autor).

Ao lado do Moço, o Menino parte de volta para casa e com ele se confunde na garupa de um cavalo, nos moldes de narrativas cavaleirescas: "A viagem devia de ser longa, com aquele Moço, que falava com o Menino, com ele tratava mão por mão, carecia de selar palavras. [...] Ah, ele tinha ira desse moço, ira de rivalidades." (ROSA, 1972, p.57). No final da narrativa, há dois encontros: na diegese, entre o Menino e os pais; no discurso, entre narrador e protagonista:

Nunca mais soube nada do Moço, nem quem era, vindo junto comigo. Reparei em meu pai, que tinha bigodes. Meu pai, estava dando ordens a dois homens que era para levantarem o muro novo, no quintal. Minha Mãe me beijou, queria saber notícias de muita gente, olhava se eu não rasgara minha roupa, se tinha ainda no pescoço, sem perder nenhuma, os santos de todas as medalhinhas. (ROSA, 1972, p. 57).

Na chegada a sua casa, o Menino olha a rotina dos pais distantes um do outro e não contém os gritos de reprovação:

"Vocês não sabem de nada, de nada, ouviram?! Vocês já se esqueceram de tudo o que, algum dia, sabiam!..."

E eles abaixaram as cabeças, figuro que estremeceram.

Porque eu desconheci meus Pais - eram-me tão estranhos; jamais poderia verdadeiramente conhecê-los, eu; eu? (ROSA, 1972, p.57 grifos do autor).

Compreende-se, no final do conto, outro significado da viagem do Menino que se pauta na compreensão do relacionamento dos pais, aparentemente, distantes um do outro: "'Vocês não sabem nada, de nada, ouviram?! Vocês já se esqueceram de tudo o que, algum dia, sabiam!..." (ROSA, 1972, p.57). A retomada do percurso da personagem infantil na diegese a fim de se explicitarem suas experiências não expôs as afirmações em primeira pessoa que se destacam, graficamente, em negrito e cortam a história. O final da narrativa quebra a ilusão, até então criada, de que narrador e personagem são distintos, reconduzindo a leitura do conto. 


\section{Considerações finais}

As versões da peça em "Pirlimpsiquice", assim como as modificações da personagem Brejeirinha para a história do audaz navegante, fazem parte da viagem ao mundo da invenção, da liberdade de criação. As personagens, inicialmente, não se dão conta do poder de inventar e não criam nova versão do drama com o intuito de usar essa liberdade. Pouco a pouco o jogo, a brincadeira de ocultar fatos e o encantamento do ato de representar prendem os atores mirins e a finalidade prática - manter o sigilo da peça verdadeira - fica em segundo plano.

Estimulados pela criatividade infantil, os garotos rompem os tênues limites entre ficção e realidade, em atitude de subversão às normas pela atividade artística, que culmina no dia exato da apresentação; o imaginado, as histórias imbricadas (a do professor, a inventada pelos atores e a do Gamboa) confundem verdade e mentira "Cada um de nós se esquecera de seu mesmo, e estávamos transvivendo, sobrecrentes, disto: que era o verdadeiro viver?"(ROSA, 1972, p. 47). A viagem dos pequenos artistas se conduz nos entremeios da irregularidade da arte, em novo território, imersos em ilusões estimulantes. 0 imaginário sobressai ao real e, ao mesmo tempo, confunde-se com fatos desencadeadores de outra realidade, mais próxima, talvez, do universo infantil da magia do contar, da habilidade de criação e recriação de cada um dos garotos. Brejeirinha, sozinha, consegue atrair ouvintes para sua narrativa ao principiar uma história por eles motivada, já as personagens de "Pirlimpsiquice", juntas, sentem-se envolvidas pelo prazer de atuar e estimuladas a participar do processo de criação artística e seu encantamento.

O enigma da viagem em "Nenhum, nenhuma" consiste em não se poder precisar se o espaço descrito corresponde a um local visitado pelo Menino ou, apenas, a visões de um sonho do narrador adulto que tenta unir fios do passado e emoldurar a essência do tempo. Traços literários diluem-se entre o gênero poético e o romanesco. As imagens dessa viagem pela memória concentram-se em linguagem sonora e sugestiva e delas o passado emerge em belíssimas descrições (extra) sensoriais, como a visão da renda antiga que se desfaz como as linhas do tecido e do tempo. 
Tênue, tênue, tem de insistir-se o esforço para algo remembrar, da chuva que caía, da planta que crescia, retrocedidamente, por espaço, os castiçais, os baús, arcas, canastras, na tenebrosidade, a gris pantalha, o oratório, registros de santos, como se um pedaço de renda antiga, que se desfaz ao se desdobrar. (ROSA, 1972, p. 52).

Explicita outro sentido para a infância revivida na experiência circular e contínua do presente, do passado e do futuro; experiência do adulto que carrega o menino e o menino que carrega o adulto, nas palavras de Cortázar:

Sempre serei como um menino para muitas coisas, mas um desses meninos que, desde o começo, carregam consigo o adulto, de maneira que, quando o monstrinho chega verdadeiramente a adulto ocorre que, por sua vez, carrega consigo o menino, e nel mezzo del cammin dá-se uma coexistência poucas vezes pacífica de pelo menos duas aberturas para o mundo. (CORTÁZAR, 2004, p. 165).

A aventura dessas viagens consiste em experimentar os caminhos possíveis da imaginação e da arte: nas águas do Aldaz Navegante, na tripla representação do drama ou no nebuloso passeio de um Menino.

\section{Referências}

AUERBACH, Erich. Mimesis. São Paulo: Perspectiva, 1994.

BACHELARD, Gaston. A poética do devaneio. São Paulo: Martins Fontes, 2001.

BENJAMIN, Walter. Reflexões sobre a criança, o brinquedo e a educação. Trad., apresentação e notas Marcus Vinicius Mazzari. São Paulo: Duas Cidades; Ed. 34, 2002.

CHOMBART-DE-LAUWE. Marie-José. Um outro mundo: a infância. Trad. Noemi Kon. São Paulo: Perspectiva-Edusp, 1991.

CUNHA, Celso Ferreira. Gramática da Língua Portuguesa. Rio de Janeiro: FENAME, 1977.

DUARTE, Lélia Parreira. Brejeirinha y otros loquitos-artistas de Guimarães Rosa. Cuardenosos Literários: el descubrimiento de Brasil, Lima, n.2, p.37-49, 2004.

FIORIN, José Luiz. As astúcias da enunciação. São Paulo: Ática, 1996.

GENETTE, Gérard. Figuras. Trad. Ivonne Floripes Mantoanelli. São Paulo: Perspectiva, 1972.

. Discurso da narrativa. Trad. Fernando Cabral Martins. Lisboa: Veja, 1995. 
LEONEL, Maria Célia de Moraes. Aparência e realidade em Guimarães Rosa. In: MARQUES, José Oscar de Almeida. Verdades e mentiras: 30 ensaios em torno de JeanJacques Rousseau. Ijuí: Unijuí, 2005. p.107-129

NUNES, Benedito. O dorso do tigre. São Paulo: Perspectiva, 1969.

PACHECO, Ana Paula Sá e Souza. Mito e processo social em Primeiras Estórias. São Paulo: USP, 2002. Tese (Doutorado em Teoria Literária e Literatura Comparada). Faculdade de Filosofia, Letras e Ciências Humanas da Universidade de São Paulo, 2002.

PERRONE-MOISÉS, Leyla. Nenhures: considerações psicanalíticas à margem de um conto de Guimarães Rosa. In: Flores da escrivaninha: ensaios. São Paulo: Cia. das Letras, 1990.

ROSA, João Guimarães. Primeiras Estórias. Rio de Janeiro: José Olympio, 1972.

RUNHO, Rosiane Cristina. O processo narratológico em contos de Primeiras Estórias. Araraquara: UNESP, 1996. Dissertação (Mestrado em Letras) - Faculdade de Ciências e Letras da Universidade Estadual Paulista, 1996.

A memória e o olhar em contos de Primeiras Estórias. Araraquara: UNESP, 2001. Tese (Doutorado em Letras) - Faculdade de Ciências e Letras da Universidade Estadual Paulista, 2001.

Recebido em junho de 2014.

Aceito em outubro de 2014. 